\title{
Scenario validation for clinical simulation: prenatal nursing consultation for adolescents
}

\author{
Validação de cenário para simulação clínica: consulta de enfermagem no pré-natal para adolescente \\ Validación de escenario para simulado clínico: consulta de enfermería en el prenatal para adolescente
}

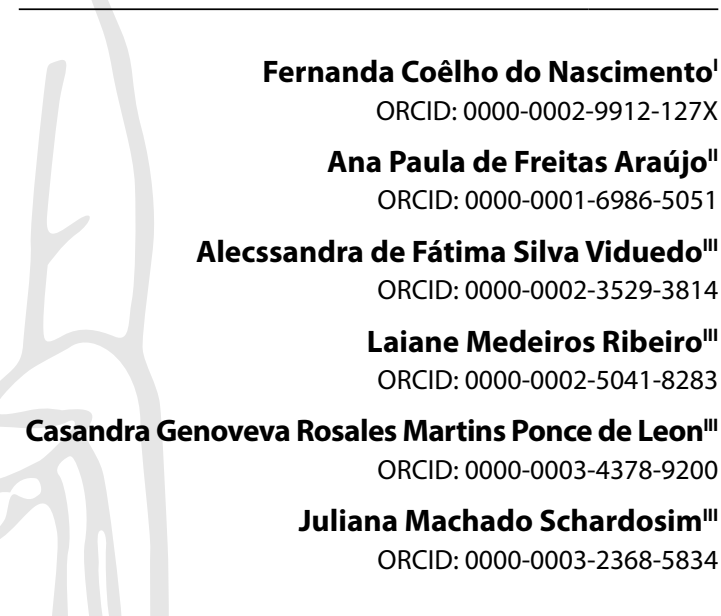

'Secretaria Estadual de Saúde de Pernambuco. Petrolina, Pernambuco. Brazil.

"Faculdade de Medicina Nova Esperança. João Pessoa

Paraíba, Brazil.

I'Universidade de Brasília. Brasília, Distrito Federal, Brazil.

How to cite this article:

Nascimento FC, Araújo APF, Viduedo AFS, Ribeiro LM, Ponce de Leon CGRM, Schardosim JM. Scenario validation for clinical simulation: prenatal nursing consultation for adolescents. Rev Bras Enferm. 2022;75(3):e20200791. https://doi.org/10.1590/0034-7167-2020-0791

\section{Corresponding author: \\ Juliana Machado Schardosim \\ E-mail: jumachadoju@hotmail.com \\ EDITOR IN CHIEF: Antonio José de Almeida Filho ASSOCIATE EDITOR: Carina Dessotte}

Submission: $07-13-2020$

Approval: 08-20-2021

\section{ABSTRACT}

Objectives: to validate a scenario for clinical simulation: prenatal nursing consultation for adolescents. Methods: methodological study developed from January to December 2019, in five stages (overview, scenario, scenario design, progression, debriefing and assessment). The validation involved four volunteer students, a teacher as a facilitator and four judges. The judges filled out a Likert scale with four responses. Data was analyzed using Microsoft Excel ${ }^{\circ}$ software, version 2016. Absolute and relative frequencies and the content validity index were calculated, considering a minimum acceptable value of 1.0. Results: the preparation of the scenario was based on the proposed learning objectives. The scenario was validated with a global content validity index equal to 1.0. Final Considerations: the study achieved the proposed objective. This scenario can contribute to preparing nurses to work in the care of pregnant teenagers, a representative public in Brazil that requires specific care.

Descriptors: Simulation Training; Education, Nursing; Obstetric Nursing; Prenatal Care; Primary Health Care.

\section{RESUMO}

Objetivos: validar um cenário para simulação clínica, no ensino de enfermagem, sobre primeira consulta de pré-natal à gestante adolescente. Métodos: estudo metodológico desenvolvido de janeiro a dezembro de 2019, em cinco etapas (overview, scenario, scenario design progression, debriefing e assessment). A validação envolveu quatro alunos voluntários, uma docente como facilitadora e quatro juízes. Os juízes preencheram uma escala Likert com quatro respostas. Os dados foram analisados no software Microsoft Excel', versão 2016. Calcularam-se as frequências absolutas e relativas e o índice de validade de conteúdo, considerando valor mínimo aceitável de 1,0. Resultados: a elaboração do cenário partiu dos objetivos de aprendizagem propostos. O cenário foi validado com índice de validade de conteúdo global igual a 1,0. Considerações Finais: o estudo alcançou o objetivo proposto. Este cenário pode contribuir para preparar enfermeiros para atuação na atenção às gestantes adolescentes, um público representativo no Brasil e que requer cuidados específicos. Descritores: Treinamento por Simulação; Educação em Enfermagem; Enfermagem Obstétrica; Cuidado Pré-Natal; Atenção Primária à Saúde.

\section{RESUMEN}

Objetivos: validar un escenario para simulado clínico, en enseñanza de enfermería, sobre primera consulta de prenatal a gestante adolescente. Métodos: estudio metodológico desarrollado de enero a diciembre de 2019, en cinco etapas (overview, scenario, scenario design progression, debriefing y assessment). La validación involucró cuatro alumnos voluntarios, una docente como facilitadora y cuatro jueces. Los jueces rellenaron una escala Likert con cuatro respuestas. Datos fueran analizados en el software Microsoft Excel', versión 2016. Calculadas las frecuencias absolutas y relativas y el índice de validez de contenido, considerando valor mínimo aceptable de 1,0. Resultados: la elaboración del escenario partió de los objetivos de aprendizaje propuestos. El escenario fue validado con índice de validez de contenido global igual a 1,0. Consideraciones Finales: el estudio alcanzó el objetivo propuesto. Este escenario puede contribuir para preparar enfermeros para actuación en la atención a gestantes adolescentes, un público representativo en Brasil y que requiere cuidados específicos. Descriptores: Entrenamiento Simulado; Educación en Enfermería; Enfermería Obstétrica; Atención Prenatal; Atención Primaria de Salud. 


\section{INTRODUCTION}

Nursing is a science; and, for their assistance to take place properly, it is necessary to improve teaching, enabling the undergraduate to acquire technical-scientific knowledge and the development of interpersonal skills in order to link the needs and expectations of students with the continuous construction of new knowledge to strengthen their professional training ${ }^{(1)}$.

Since the emergence of modern nursing, with Florence Nightingale, the teaching of the profession has evolved. The need to strengthen the nurse's curriculum with skills and knowledge that worked in an integrated manner was perceived, making it more general, humanistic, detailed and reflective ${ }^{(2)}$.

The constant production of knowledge in nursing concerns the changes made over the years in their academic qualifications caused by the growing scientific recognition that has been reinvigorating and qualifying both this professional and the care provided by them ${ }^{(2)}$. Simulation enters this context as an effective scientific method for improving the skills and competences of students, as well as professionals already in the labor market ${ }^{(3)}$.

Clinical simulation, in addition to improving students' skills and competences in terms of technique, contributes to their professional training within the ethical-legal and patient safety aspects. This is because the practice in a controlled environment enables the reduction of adverse events in real practice environments, that is, it causes a reduction in the patient's risk due to the insecurity and inexperience of the student. Another advantage is the development of a critical view of their own conduct, so that successes and errors can be identified and corrected $^{(4-5)}$.

In this context, clinical simulation represents an innovation in nursing education, while scenario validation studies are configured as an innovation regarding the scientificity of this teaching method. For teachers, being able to use a validated scenario increases the confidence that it was developed with scientific rigor and based on the most recent evidence ${ }^{(6)}$.

The autonomy of nurses in prenatal care requires technicalscientific preparation from students. Simulation is a method that favors the development of skills related to posture during the consultation, such as qualified listening skills and effective communication; technical-scientific skills, such as scientific knowledge about the puerperal pregnancy cycle, obstetrical propaedeutics and prenatal care, risk classification, consultation guide, recommended exams, pregnant woman's vaccination schedule and systematization of nursing care.

Validation studies of scenarios for clinical simulation in maternal, child and obstetric nursing care are still scarce. Therefore, this work aimed to fill this gap in knowledge and encourage other researchers to develop new validated scenarios.

\section{OBJECTIVES}

To validate a scenario for clinical simulation, in nursing education, about the first prenatal consultation for pregnant adolescents.

\section{METHODS}

\section{Ethical aspects}

The study was approved by the Research Ethics Committee, respecting the norms of Resolution 466/12 of the National Health Council ${ }^{(7)}$. Acceptance to participate in the study occurred by signing two copies of the Informed Consent Form and the Authorization Form for the Use of Image and Sound signed by students and judges.

\section{Design, period, and place of study}

This is a methodological research that adopted as a reference Guilbert and Adamson (2016) ${ }^{(8)}$, based on recommendations from the International Nursing Association for Clinical Simulation and Learning (INACSL). This method proposes five phases for developing scenario validation studies: overview, scenario, scenario design progression, debriefing and assessment.

The project was developed from January to December 2019. The assessment stage, which consists of on-site validation, took place on November 20, 2019, at the Care Skills and Simulation Laboratory (LHSC), of a public university in the Federal District. This stage consisted of presenting the scenario to the judges, with an average duration of 75 minutes (5 minutes of pre-briefing, 20 minutes of briefing, 10 minutes of debriefing and about 10 minutes for each judge to make their questions and comments on the preparation of the scenario and debriefing checklist).

\section{Population; inclusion and exclusion criteria}

The validation of the scenario involved a total of nine volunteer participants, being a teacher, four actors (two representing the roles of the scenario and two representing the students inserted in the scenario) and four judges. The professor was the supervisor of this study, the actors were students of the Nursing course at the University of Brasília - Faculty of Ceilândia, and the judges were professionals with knowledge about the theme of the scenario.

For the inclusion of judges, a minimum of 4 points was considered according to the Judges Scoring System, adapted from Góes et al. (2014) ${ }^{(9)}$, which included aspects related to training, professional experience and scientific production. Each item on training was worth 1 point (award for a doctorate, master's, and specialization). In case of specialization in obstetrics, 1 more point. Items related to professional practice (assistance or teaching) and publications (on obstetrics or simulation) were worth 2 points, with a sum being made for each judge. For the students, approval in the subject with contents on women's and children's health in the Nursing course of the university in which the study was developed was considered an inclusion criterion.

For the judges, professionals in positions that did not allow their direct clinical performance for two years or more were excluded, as it was understood that they might not be aware of recent scientific updates, impairing their assessment of the simulated scenario. For students, there were no exclusion criteria. 


\section{Study protocol}

The selection of study participants was by convenience. To select the judges, a search was carried out on the Lattes Platform to help verify the inclusion and exclusion criteria before sending the invitations, which took place by email. Out of a total of five invitations, four were accepted. Students were invited to participate in the scenario through dissemination on the university campus through direct contact with the study researchers. Two students participated in the role of nurses and had no prior knowledge of the scenario, however, a week earlier, they received a list with five themes, to review the contents that had some relationship with the case; this provided that the evaluation was trustworthy. Two other students were invited to participate as actresses in the roles of the teenager and her mother. With these students, a preliminary meeting was held about a week before the simulation, in which they learned about the script they would have to follow for the scenario to take place as planned.

As this is a methodological study, it was not possible to adopt any of the tools proposed by the EQUATOR network. Before the first stage of the study, the researchers performed in-depth readings on official materials produced by the Ministry of Health of Brazil, WHO, scientific articles and textbooks, resulting in a compilation of scientific evidence on the theme of the scenario(10-11). This survey provided the opportunity for the preparation of the scenario based on updated knowledge, for the subsequent steps.

The first stage (overview) corresponded to an initial reflection based on theoretical knowledge, to define the proposed learning objectives for the scenario under development. In addition, at this stage, the needs of the educator were defined, which relate to the content suggested to be worked on in the classroom, before inserting the students into the scenario.

The second stage (scenario) referred to the development of the initial idea for the construction of the scenario. At this point, only basic aspects of the clinical case are defined to meet the learning objectives proposed in the previous step.

The third step (scenario design progression) concerns the development of all the details of the scenario, based on the definitions of the previous step. At this point in the study, the roles, and their lines (scripts), costumes and the entire list of material elements necessary for setting up the scenario were defined.

The fourth stage (debriefing) corresponded to the elaboration of an evaluative checklist to compose the instrument to be used by the professor in the debriefing during the simulation. This guides the evaluation process while the scenario takes place and guides the student-teacher discussion in the debriefing itself. This instrument also considers the learning objectives defined in the first stage.

The fifth step (assessment) is related to the on-site validation itself. In order for the judges to be able to visualize the applicability of the scenario in nursing education, a representation of all stages of clinical simulation in teaching (pre-briefing, briefing and debriefing) was performed. At the end of this process, each judge was able to make a verbal and a written assessment about the scenario and checklist for debriefing proposed by the researchers. It is noteworthy that, at this stage of the study, the judges had access to all the documentation produced in the previous stages.

\section{Analysis of results and statistics}

Data were analyzed using Microsoft Excel ${ }^{\circ}$ software, version 2016. To validate the scenario, the content validation index (CVI) was calculated. The CVI is a measure of the judges' agreement on the topics evaluated on the elaborated scenario. The calculation of the CVI was based on the completion of a Likert scale with four response alternatives (Totally inadequate; Inadequate, but it can be redone; Adequate with minor adjustments; and totally adequate), the last two being considered for validation purposes. The minimum acceptable value of CVI for scenario validation was 1.0 , following the literature recommendation for a body of six judges or less ${ }^{(12)}$.

\section{RESULTS}

After deciding on the topic to be addressed and surveying up-to-date scientific evidence, the learning objectives were proposed for this simulation. The general objective defined was: "To carry out the first prenatal consultation, as recommended by the Ministry of Health, and to manage verbal communication with the adolescent's mother". Other linked objectives were "To verify the students' knowledge about the prenatal consultations schedule, the first consultation schedule, the prescription of exams for the first trimester and the vaccination schedule; intermediation of conflicts between the adolescent and her mother present at the consultation", as well as the communication and attitude of the nurse towards the adolescent public.

Based on the defined objectives, the other aspects related to the scenario were aligned. This scenario is classified as low complexity and high fidelity ${ }^{(13)}$ because it is a situation with actors who faithfully reproduce the reality of a first prenatal consultation with a pregnant teenager, when there are no evident anatomical changes yet. As the first prenatal consultation includes a complete anamnesis and filling out different documents in the Basic Health Unit (BHU), the time of up to 30 minutes was considered for the execution of the scenario and the insertion of one to two students in the situation.

As for the environment, it was necessary to reproduce a BHU office with a table, chairs, stretcher, decorative objects (posters, calendar), medical materials (sphygmomanometer, stethoscope, tape measure, obstetric sonar, procedure gloves, quick tests, alcohol, cotton, lancets). With regard to the pregnant woman, an actress characterized as an adolescent with some devices that favored the performance of the physical examination was suggested, such as: breast prosthesis and silicone pelvis. It is believed that interacting with an actress in the role of pregnant woman makes the scene more real for students than using a dummy/simulator. Below is a description of the scenario with the main lines of the script (Chart 1).

With the scenario ready, the instrument was designed to guide the teacher in the assessment of students and the dialogue in the debriefing. In validation, an instrument for debriefing was chosen, which added to the evaluative checklist questions that encouraged students to verbalize their feelings and sensations during the execution of the simulated scenario ${ }^{(14)}$. Chart 2 presents this instrument. 
Chart 1 - Description of the validated scenario "First prenatal consultation performed by the nurse with an adolescent pregnant woman", Brasília, Distrito Federal, Brazil, 2019

\section{Brief description of the scenario:}

A 15-year-old teenager, with a positive pregnancy test, arrives at the Basic Health Unit accompanied by her mother. After screening, mother and daughter are referred for consultation with nurses to start prenatal care. At screening, the following vital signs and anthropometric measurements are observed: Blood pressure: $110 \times 70$ mmHg; Respiratory rate: 17 bpm; Heart rate: 90 bpm; Saturation: 97\%; Weight: 60 kg; Height: 1.62 m. Blood Type: B+.

\section{Script:}

Since the consultation is conducted by the nurse, there is no way to predict the ready-made speeches of the actresses for the students' questions (nurses). Based on the memorization of the character's story, the actresses are free to respond as they are questioned. From the beginning of the conversation, the mother of the pregnant woman will take the initiative to answer everything for her. The teenager will try to speak but will not have space. If the students (nurses) ask her to leave, she will be resistant. Here are the necessary data for the anamnesis.

- Family history: diabetic mother and diabetic father. Denies other comorbidities in the family, alleges a history of twin pregnancy in the family. - Personal history: denies illnesses and health problems, has never undergone surgery before; denies having had anemia and having recurrent cases of urinary tract infection. He never had a Pap smear.

- Gynecological and obstetric history: menarche at 13 years of age, sexarche at 14 years of age, regular menstrual cycles lasting an average of 28 days and menstrual phase lasting about 5 days. Has no history of recurrent vaginal infections. She is primigravid, with no history of previous miscarriages. Last menstruation date is compatible with an 8-week pregnancy on the day the simulation is performed.

- History of current pregnancy: unplanned pregnancy. She reports that, during a party, she had sex with several people, but she cannot say who the child's father is. The mother of the pregnant woman seems very irritated with the situation. The pregnant woman denies having knowledge about contraceptive methods and blames the mother for never having talked to her about the subject. So far, the pregnant woman has not had vaginal bleeding. She denies nausea or vomiting. Pregnant women drink less than 1 liter of water a day and do not like to eat leafy foods, fruits, or vegetables; she eats all kinds of meat and is very fond of pasta and fast food. The mother of the pregnant woman claims to have lost her vaccination card while moving house.

- On examination: rapid tests, all negative (performed in screening). Pregnant woman presents symmetrical breasts and inverted right nipple, absence of nodules on palpation, absence of secretion on manual expression. Flat abdomen, no palpable masses. External genitalia without alterations and extremities with good perfusion and absence of edema or varicose veins.

- If the student (nurse) is unable to conduct the anamnesis, the characters can use lines to alert them, for example:

Pregnant woman: Why do I need to take this medication (iron)?

Mother: And now, nurse, when does this girl have to come back here? I don't want her skipping class every week.

Mother: And when does she need tests? I remember my pregnancy was a bunch of exams.

Pregnant woman: How long is my baby now? Will it take me to feel it move?

Chart 2 - Evaluation checklist for debriefing the validated scenario, Brasília, Distrito Federal, Brasil, 2019

\begin{tabular}{|c|c|c|c|c|c|}
\hline & Skills and knowledge expected from students & NP & $\mathbf{I}$ & PA & A \\
\hline \multirow{3}{*}{ 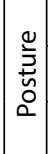 } & They introduced themselves and received the teenager and her mother respectfully. & & & & \\
\hline & They handled the teenager's mother, giving the two a space for dialogue (mediation of conflicts). & & & & \\
\hline & They explained all the procedures to the pregnant woman before performing them. & & & & \\
\hline \multirow{8}{*}{ 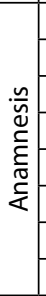 } & They investigated family history. & & & & \\
\hline & They investigated personal background. & & & & \\
\hline & They investigated obstetric and gynecological history. & & & & \\
\hline & They investigated the current pregnancy. & & & & \\
\hline & They investigated the pregnant woman's lifestyle and routine. & & & & \\
\hline & They investigated the need to collect Pap smears. & & & & \\
\hline & They verified the vaccination status. & & & & \\
\hline & They calculated GI and PDP, based on the informed DLM. & & & & \\
\hline \multirow{14}{*}{$\begin{array}{l}\tilde{y} \\
\frac{0}{2} \\
\frac{0}{0} \\
0\end{array}$} & They performed a complete cephalocaudal physical examination. & & & & \\
\hline & They performed a gynecological examination (breasts and perineum). & & & & \\
\hline & They explained the consultation schedule and the importance of the PC. & & & & \\
\hline & Advised on the recommended vaccines for pregnant women. & & & & \\
\hline & They requested the exams recommended in the Primary Care Notebook 32 (BRASIL, 2012a). & & & & \\
\hline & They prescribed ferrous sulfate and folic acid. & & & & \\
\hline & They provided guidance on educational activities, pregnant women's rights, and the importance of family participation in prenatal care. & & & & \\
\hline & Indicated natural ways to minimize nausea/nausea. & & & & \\
\hline & Advised on food and water intake during pregnancy. & & & & \\
\hline & They provided guidance on the repercussions of drug and medication use during pregnancy. & & & & \\
\hline & They advised on physical activities during pregnancy. & & & & \\
\hline & They provided guidance on sexual practices and STIs during pregnancy. & & & & \\
\hline & They provided guidance on abortion warning signs and other changes that require professional care before the next appointment. & & & & \\
\hline & They filled in the pregnant woman's booklet. & & & & \\
\hline
\end{tabular}


After the development of the scenario and checklist for the debriefing, the judges were selected and invited for on-site validation. Four judges who achieved the minimum required score were included. Two judges scored 7; and two others, 9 and 16. All had graduate degrees and clinical experience, teaching or research in maternal and child health or with clinical simulation. Some had already been judges in other validation studies. Table 1 presents their profiles.

Table 1 - Characterization of study judges, Brasília, Distrito Federal, Brazil, 2019

\begin{tabular}{|c|c|c|}
\hline & $\mathbf{n}$ & $\%$ \\
\hline Age (years)* & $27.25 \pm 0.96$ & \\
\hline $\begin{array}{l}\text { Education } \\
\text { Graduation in Nursing }\end{array}$ & 4 & 100 \\
\hline $\begin{array}{l}\text { Graduate degrees } \\
\text { Specialization } \\
\text { Master's degree } \\
\text { Doctorate degree }\end{array}$ & $\begin{array}{l}2 \\
2 \\
0\end{array}$ & $\begin{array}{l}50 \\
50 \\
00\end{array}$ \\
\hline $\begin{array}{l}\text { Professional performance } \\
\text { Assistance } \\
\text { Teaching } \\
\text { Postgraduate student }\end{array}$ & $\begin{array}{l}1 \\
4 \\
3\end{array}$ & $\begin{array}{c}25 \\
100 \\
75\end{array}$ \\
\hline Time of experience (years) ${ }^{*}$ & $4.75 \pm 1.5$ & \\
\hline $\begin{array}{l}\text { Simulation experience } \\
\text { Teacher } \\
\text { Researcher } \\
\text { Participation as a judge previously }\end{array}$ & $\begin{array}{l}4 \\
2 \\
3\end{array}$ & $\begin{array}{c}100 \\
50 \\
75\end{array}$ \\
\hline Simulation experience time ${ }^{\S}$ & $2.5(2.0-3.75)$ & \\
\hline Publications in the area of women's health & 2 & 50 \\
\hline Publications on clinical simulation & 1 & 25 \\
\hline
\end{tabular}

In the validation process, after watching a teaching activity simulation with the elaborated scenario, the judges filled out the Likert scale, evaluating different issues related to the scenario and instrument for debriefing. The aspects evaluated were the same as in the study by Ponce de Leon et al. $(2018)^{(15)}$, adapted from Medeiros et al. $(2015)^{(6)}$. Based on these records, the CVI was calculated, as shown in Table 2.

At the end of the process, each judge was able to express verbally or in writing their impressions, questions, or suggestions for changing the scenario or checklist. All comments were analyzed, and those considered relevant to improve the scenario were inserted.

In the scenario, there were adjustments in the educator's needs, which are the contents suggested for the educator to work in the theoretical class before the simulation is carried out. The Women's Health Protocol, published in $2016^{(16)}$, was included in the references suggested for that moment. In the student's learning needs (goals), it was included that he should demonstrate knowledge about the protocols of the first appointment, which include, among other items, the request for prenatal exams, vaccination coverage and filling in the charts in the booklet.

In the debriefing instrument, the expected posture of the students was added to deal with conflict mediations, and the item to advise on the use of drugs and medications during pregnancy and to advise on sexually transmitted infections during pregnancy was added.

\section{DISCUSSION}

Adolescence corresponds to the period from 10 to 19 years of life. Pregnancy in this population group has been considered a public health problem in several countries, as it can lead to obstetric complications, social problems and family conflicts ${ }^{(17)}$.

Data from the Information System on Live Births (SINASC) indicate, on the one hand, a decline in the birth rate in Brazil; on the other hand, they indicate a relative increase in babies born to teenage mothers. In 2018, there were 456,128 births whose parturients were between 10 and 19 years old; this data corresponds to approximately $15.5 \%$ of total births in Brazil in this period ${ }^{(18)}$.

Table 2 - Judges' evaluation of the scenario "First prenatal consultation performed by the nurse with an adolescent pregnant woman", Brasília, Distrito Federal, Brazil, 2019

\begin{tabular}{|c|c|c|c|c|c|c|c|c|c|}
\hline \multirow[t]{2}{*}{ Items rated } & \multicolumn{2}{|c|}{$\begin{array}{c}\text { Totally } \\
\text { inappropriate }\end{array}$} & \multicolumn{2}{|c|}{$\begin{array}{l}\text { Inappropriate } \\
\text { but can be } \\
\text { redone }\end{array}$} & \multicolumn{2}{|c|}{$\begin{array}{c}\text { Adequate } \\
\text { with minor } \\
\text { adjustments }\end{array}$} & \multicolumn{2}{|c|}{$\begin{array}{c}\text { Totally } \\
\text { adequate }\end{array}$} & \multirow[t]{2}{*}{ CVI } \\
\hline & $\mathbf{n}$ & $\%$ & $\mathbf{n}$ & $\%$ & $\mathbf{n}$ & $\%$ & $\mathbf{n}$ & $\%$ & \\
\hline Clinical case plausibility & - & - & - & - & - & - & 4 & 100 & 1.0 \\
\hline Realism & - & - & - & - & - & - & 4 & 100 & 1.0 \\
\hline Adherence to available scientific evidence & - & - & - & - & 1 & 25 & 3 & 75 & 1.0 \\
\hline Complexity in relation to the student's level of knowledge and skills & - & - & - & - & 1 & 25 & 3 & 75 & 1.0 \\
\hline case description & - & - & - & - & - & - & 4 & 100 & 1.0 \\
\hline Simulation objectives provided to the student & - & - & - & - & - & - & 4 & 100 & 1.0 \\
\hline Information provided to the student before the simulation & - & - & - & - & - & - & 4 & 100 & 1.0 \\
\hline Data provided to the student during the simulation & - & - & - & - & - & - & 4 & 100 & 1.0 \\
\hline Support provided to the student during the simulation & - & - & - & - & - & - & 4 & 100 & 1.0 \\
\hline Learning Objectives & - & - & - & - & - & - & 4 & 100 & 1.0 \\
\hline Promotion of critical thinking & - & - & - & - & - & - & 4 & 100 & 1.0 \\
\hline Promoting the ability to prioritize nursing assessments and interventions & - & - & - & - & - & - & 4 & 100 & 1.0 \\
\hline Promotion of autonomous problem solving & - & - & - & - & 1 & 25 & 3 & 75 & 1.0 \\
\hline Simulator/actress parameters consistent with the clinical case & - & - & - & - & - & - & 4 & 100 & 1.0 \\
\hline simulated environment & - & - & - & - & - & - & 4 & 100 & 1.0 \\
\hline Materials and equipment available to students & - & - & - & - & - & - & 4 & 100 & 1.0 \\
\hline Aspects evaluated in the debriefing & - & - & - & - & - & - & 4 & 100 & 1.0 \\
\hline Reflection and analysis of actions in debriefing & - & - & - & - & - & - & 4 & 100 & 1.0 \\
\hline Synthesis and student feedback in debriefing & - & - & - & - & - & - & 4 & 100 & 1.0 \\
\hline Mean CVI & & & & & & & & & 1.0 \\
\hline
\end{tabular}

$\mathrm{CVI}$ - content validation index. 
Pregnancy can be well tolerated by teenagers when they have access to quality prenatal care with an early start. Adolescent pregnancy is a phenomenon associated with social vulnerability. A study published on the profile of teenage mothers in the south and southeast of Minas Gerais identified that most were single and had schooling time compatible with their ages. However, the authors point out that normally pregnant teenagers have incomplete prenatal care associated with the issue of trying to hide the pregnancy ${ }^{(19)}$.

Knowing the importance of the quality of prenatal care to reduce maternal-fetal morbidity and mortality ${ }^{(10)}$ and knowing the main problems faced by these young mothers, it is of paramount importance to train nursing students for professional practice. The clinical simulation involving the theme allows future nurses to have contact with this reality in the form of a staging, so that they feel more secure when performing this type of care in their future professional life.

Clinical simulation enables the fixation of theoretical contents taught prior to the reproduction of simulated clinical cases. This theoretical-practical association allows the student to realize the real importance of the applicability of correct techniques relevant to the profession and the improvement of skills necessary for the clinical case in question ${ }^{(20)}$. In this sense, a study with 93 nursing students in Taiwan found: students who underwent simulation performed better with regard to the safe administration of medications than students who had only teaching based on problematization ${ }^{(21)}$.

It is known that, during their appointments, nurses need critical, reflective, and agile reasoning, whose development is aided by teaching through simulation through repetitive contact with clinical situations in a controlled environment, which allow the student to make mistakes and correct their mistakes without causing real damage. In this regard, simulation has been adding technical and non-technical knowledge to nursing students, which can be considered key to their professional performance ${ }^{(22-24)}$. In a systematic review study on the impact of educational interventions on nursing students to develop communication skills with patients, simulation was described in 11 of the 19 studies included. Based on the findings, either authors reinforce simulation as a methodology for training communication skills, obtaining statistical significance in the results ${ }^{(25)}$.

For the simulation to be useful in teaching, it is important that the preparation of the scenario has the learning objectives as a starting point ${ }^{(26)}$. Therefore, the scenario validation method places the definition of objectives in the first stage, so that all actions developed in subsequent stages must aim to meet these objectives. Therefore, the issue of the methodological rigor of the scenario validation process and its importance in teaching is highlighted.

In this study, a little complex was sought out to be created, but high-fidelity scenario, to give students the opportunity to think about the intrinsic needs of pregnant teenagers and how to manage a mother who thought they have the right to answer for their youngest daughter. Clinical aspects related to prenatal care can be worked on in scenarios with pregnant women of other profiles but approaching an adolescent with clinical changes would entail the need for more time to carry out the scenario, which could make its use in future teaching activities unfeasible.

The validation of the scenario aims to assess whether it fulfills its purpose and whether it is reproducible as an innovative teaching tool. For the validation to take place reliably, the participation of judges with experience in the content area and previous experience in simulation is necessary ${ }^{(27)}$. As it is a maternal-infant simulation and it is still not widespread in Brazil, given that publications of validated scenarios in this area are scarce, it was difficult to find judges who met the inclusion criteria, which made the body of judges somewhat restricted, but in accordance with the validation standards.

Given the number of judges included in the study, the recommendation in the literature was to seek a CVI of not less than 1.0. In studies with a larger number of judges, this value may be lower ${ }^{(12)}$. In the present study, the validated scenario obtained a CVI of 1.0, representing that the judges agreed $100 \%$ on the items evaluated.

A study that validated a scenario on the role of nurses in the care of adolescents with alcohol and drug abuse and another scenario on care for adolescent pregnant women, the CVI of 0.75 was defined as a minimum value for the validation of the scenario; and the CVI obtained was 0.81 for both scenarios ${ }^{(15)}$. Another study, which validated the scenario of nursing management in situations of postpartum hemorrhage, stipulated a CVI of 0.80 as a minimum value; and the researchers achieved a CVI of $0.976^{(27)}$.

In addition to completing the instruments that led to the numerical interpretation of the results through the CVI, there was a space for the judges to talk about their assessment and about the aspects that could be improved in the scenario and in the checklist. This dialogue was very rich in defining the final version of the scenario. Although it was not the objective of this study, the students involved in the demonstration of the scenario to the judges were also able to give their opinion verbally and freely, contributing so that students who will be submitted to this scenario in the future feel more confident. It is important that students arouse interest in the material presented and realize the relevance of the topic and the way it was taught for their academic and future professional life ${ }^{(27)}$.

In teaching, debriefing is the most important stage of simulation, as it is the final stage of simulated practice and represents a moment of exchange between students and teachers. It consists of a moment of reflection on what was staged, and students have the opportunity to talk about their performance within the scenario and highlight their positive points, as well as points for improvement. At this point, the teacher also asks the students some questions, in order to know how much theoretical background the students have, as the nervousness of being in the scene can sometimes be considered a negative point that can lead students to conduct inadequate or even not carrying out actions considered important, even if they have mastery of them ${ }^{(15)}$.

In order to standardize the assessment of the facilitators who will use this teaching tool in the future, the debriefing instrument was validated in this study. As a way to systematize it, the aspects evaluated were divided into three points (posture, anamnesis and behavior). The suggestions raised by the judges about the proposed checklist for the debriefing allow the assessment instruments to become close to the desired goals in teaching-learning 
and benefit the student through the active methodology, that is, in which he is the center of the process of training ${ }^{(28)}$.

\section{Study limitations}

The limited number of judges was considered a limitation of the study, but professionals with an available schedule who met the inclusion criteria to participate in the validation were not found. Another limitation is that the scenario was designed according to the reality of the Federal District; therefore, it may need adaptations for use in teaching in other states in Brazil.

\section{Contributions to the area of Nursing, Health or Public Policy}

Considering both teenage pregnancy as a globally recognized public health problem and all the social issues that permeate it, this study contributes to the preparation of nurses to face this reality. More qualified nurses can intervene in different ways to try to reduce the occurrence of early pregnancy or even help in the formation of bonds with these families, in order to smooth the impacts of motherhood at this stage of life.

Furthermore, this study gives visibility to one of the active teaching methodologies, clinical simulation, which represents an advance in the role of students in the teaching-learning process. Student-centered teaching encourages self-confidence and proactivity from academia, developing in-training students essential qualities for their chosen profession.

\section{CONCLUSIONS}

The study achieved the proposed objective of validating a scenario for clinical simulation focused on nursing education. Although simulation is not such a new method in nursing, it is still little used in Brazil due to the demand of time for the elaboration of scenarios and due to the structural needs in educational institutions for its assembly. The scenario validation method is much more recent, and the publication of this type of study is still scarce.

It is understood that this scenario can contribute to the preparation of nursing students for the work aimed at attention to pregnant adolescents, a representative public in Brazil and that requires specific care. In addition, it is expected that clinical simulation becomes increasingly scientific, that this study encourages other researchers to develop scenarios for different areas of nursing and that this scenario can be adopted in different educational institutions across Brazil. The intention is to collaborate with innovations in nursing education.

\section{REFERENCES}

1. Dessotte CAM, Teixeira ASM, Sousa CDA, Sonobe HM. Teaching strategies in perioperative nursing: a student assessment. Rev Sobecc. 2015;20(4):189-96. https://doi.org/10.5327/Z1414-4425201500040002

2. Serra MN. Learning to be a nurse: professional identity in nursing students. Sisifo Educ Sci J [Internet]. 2016[cited 2020 Mar 27];(5):69-80. Available from: http://sisifo.ie.ulisboa.pt/index.php/sisifo/article/view/93/148

3. Costa RRO, Medeiros SM, Martins JCA, Menezes RMP, Araújo MS. O uso da simulação no contexto da educação e formação em saúde e enfermagem: uma reflexão acadêmica. Rev Espaco Saude. 2015;16(1):59-65. https://doi.org/10.22421/1517-7130.2015v16n1p59

4. Figueiredo AE. Laboratório de enfermagem: estratégias criativas de simulações como procedimento pedagógico. Rev Enferm UFSM. 2014;4(4):844-9. https://doi.org/10.5902/2179769211474

5. Mesquita HCT, Santana BS, Magro MCS. Effect of realistic simulation combined to theory on self-confidence and satisfaction of nursing professionals. Esc Anna Nery. 2019;23(1):e20180270. https://doi.org/10.1590/2177-9465-EAN-2018-0270

6. Medeiros RKS, Ferreira Júnior MA, Torres GV, Vitor AF, Santos VEP, Barrichello E. Instrument content validation on nasogastric intubation skills. Rev Eletron Enferm. 2015;17(2):278-89. https://doi.org/10.5216/ree.v17i2.28820

7. Ministério da Saúde (BR), Conselho Nacional de Saúde. Resolução n 466, 2012. Diretrizes e normas regulamentadoras de pesquisa envolvendo seres humanos [Internet]. Brasília, DF: MS; 2012[cited 2020 Apr 12]. Available from: https://bvsms.saude.gov.br/bvs/saudelegis/ cns/2013/res0466_12_12_2012.html

8. Guilbert M, Adamson KA. Making sense of methods and measurement: validation part II. Clin Simul Nurs. 2016;12(7):275-6. https://doi. org/10.1016/j.ecns.2016.02.006

9. Góes FSN, Dalri MCB, Fonseca LMM, Canini SRMS, Scochi CGS. Desenvolvimento de casos clínicos para o ensino do raciocínio diagnóstico. Rev Eletron Enferm. 2014;16(1):44-51. https://doi.org/10.5216/ree.v16i1.20564

10. Ministério da Saúde (BR). Atenção ao pré-natal de baixo risco [Internet]. Brasília, DF: MS; 2012[cited 2020 Apr 10]. (Cadernos de Atenção Básica, n. 32). Available from: http://bvsms.saude.gov.br/bvs/publicacoes/cadernos_atencao_basica_32_prenatal.pdf

11. Organização Mundial da Saúde. Diretriz: suplementação diária de ferro e ácido fólico em gestantes [Internet]. Genebra: OMS; 2013[cited 2020 Apr 10]. Available from: http://189.28.128.100/dab/docs/portaldab/documentos/guia_gestantes.pdf

12. Alexandre NMC, Coluci MZO. Validade de conteúdo nos processos de construção e adaptação de instrumentos de medida. Cienc Saude Colet. 2011;16(7):3061-8. https://doi.org/10.1590/S1413-81232011000800006.

13. Meakim C, Boese T, Decker S, Franklin AE, Gloe D, Lioce L, et al. Standards of best practice: simulation standard I: terminology. Clin Simul Nurs. 2013;9(65);S3-11. https://doi.org/10.1016/j.ecns.2013.04.001

14. Jeffries PR, Rogers KJ. Theoretical framework for simulation design. In: Jeffries PR, editor. Simulation in nursing education: from conceptualization to evaluation. New York: National Leag for Nursing. 2007. p. 21-33. 
15. Ponce de Leon CGRM, Silva AK, Ribeiro LM, Brasil GC, Guarda LEA, Fonseca LMM. Development and validation of clinical cases to be used in maternal-child nursing education. Rev Enferm Referencia. 2018;4(18):51-62. https://doi.org/10.12707/RIV18013

16. Ministério da Saúde (BR). Protocolos da atenção básica: saúde das mulheres [Internet]. Brasília, DF: MS; 2016[cited 2020 Apr 12]. Available from: http://bvsms.saude.gov.br/bvs/publicacoes/protocolos_atencao_basica_saude_mulheres.pdf

17. Fernandes RFM, Rodrigues AP, Soares MC, Corrêa ACL, Cardoso SMM, Krebs EM. Obstetric intercorrences occurring during pregnancy in adolescence. Cienc Cuid Saude. 2018;17(1):1-7. https://doi.org/10.4025/cienccuidsaude.v17i1.39057

18. Ministério da Saúde (BR). Nascidos vivos por região [Internet]. Brasília, DF: MS; 2018[cited 2020 Apr 12]. Available from: http://tabnet. datasus.gov.br/cgi/tabcgi.exe?sinasc/cnv/nvuf.def

19. Ribeiro ME, Pillon SC, Gradim CVC. Gravidez em adolescents: análise da macrorregião do sul/sudoeste de Minas Gerais, Brasil. Adolesc Saude [Internet]. 2018[cited 2020 Apr 11];15(3):60-8. Available from: https://s3-sa-east-1.amazonaws.com/publisher.gn1.com.br/ adolescenciaesaude.com/pdf/v15n3a08.pdf

20. Costa RRO, Medeiros SM, Martins JCA, Cossi MS, Araújo MS. Percepção de estudantes da graduação em enfermagem sobre a simulação realística. Rev Cuidarte. 2017;8(3):1799-808. https://doi.org/10.15649/cuidarte.v8i3.425. Portuguese.

21. Kuo S-Y, Wu J-C, Chen H-W, Chen C-J, Hu SH. Comparison of the effects of simulation training and problem-based scenarios on the improvement of graduating nursing students to speak up about medication errors: a quasi-experimental study. Nurse Educ Today. 2020;87:104359. https://doi.org/10.1016/j.nedt.2020.104359

22. Powers K. Bringing simulation to the classroom using an unfolding video patient scenario: a quasi-experimental study to examine student satisfaction, self-confidence, and perceptions of simulation design. Nurse Educ Today, 2020;86:104324. https://doi.org/10.1016/j. nedt.2019.104324

23. Rodríguez-Díez MC, Dienz-Goñi N, Beunza-Nuin JJ, Auba-Guedea M, Olaertecoaechea-Linaje B, Ruiz-Zambraba A, et al. Confidence assessment among medical students trained with an obstetric simulator. An Sist Sanit Navar. 2013;36(2):275-80. https://doi.org/10.4321/ s1137-66272013000200010

24. Baptista RCN, Martins JCA, Pereira MFCR, Mazzo A. Simulação de alta-fidelidade no curso de enfermagem: Ganhos percebidos pelos estudantes. Rev Enferm Referencia. 2014;4(1):135-44. https://doi.org/10.12707/RIII13169.

25. Gutiérrez-Puertas L, Márquez-Hernández VV, Gutiérrez-Puertas V, Granados-Gámez G, Aguilera-Manrique G. Educational interventions for nursing students to develop communication skills with patients: a systematic review. Int J Environ Res Public Health. 2020;17(7):2241. https://doi.org/10.3390/ijerph17072241

26. Gutierrez F, Quilici, AP. Simulação clínica: do conceito à aplicabilidade. São Paulo: Atheneu; 2012.

27. Andrade PON, Oliveira SC, Morais SCRV, Guedes TG, Melo GP, Linhares FMP. Validation of a clinical simulation setting in the management of postpartum haemorrhage. Rev Bras Enferm. 2019;72(3):656-63. https://doi.org/10.1590/0034-7167-2018-0065

28. Becerra JB, Hernández NE, Castro AM. Validación de guías de autoaprendizaje en simulación clínica para estudiantes de enfermería. Rev Cuidarte. 2017;8(2):1582-90. https://doi.org/10.15649/cuidarte.v8i2.377 